\title{
Costs of Nutrient Losses in Priceless Soils Eroded From the Highlands of Northwestern Ethiopia
}

\author{
Yihenew G.Selassie $^{1}$ \& Yihenew Belay $^{2}$ \\ ${ }^{1}$ College of Agriculture and Environmental Sciences, Bahir Dar University, Ethiopia \\ ${ }^{2}$ Woreta Agricultural Technical Vocational Education and Training College, Ethiopia \\ Correspondence: Yihenew G. Selassie, Department of Natural Resources Management, College of Agriculture \\ and Environmental Sciences, Bahir Dar University, Bahir Dar, Ethiopia. Tel: 251-918-765-823. \\ E-mail: yihenewgs@gmail.com
}

Received: April 30, 2013 Accepted: June 5, 2013 Online Published: June 16, 2013

doi:10.5539/jas.v5n7p227 URL: http://dx.doi.org/10.5539/jas.v5n7p227

\begin{abstract}
A study was conducted in 2011 to estimate soil and nutrient losses caused by water erosion and predict nutrient replacement costs on different land use types and slope classes at Harfetay watershed, Northwestern Ethiopia. The revised soil loss equation (RUSLE) was used to estimate the soil loss from the different land uses and slope classes in watershed. Moreover, nutrient loss from similar units was calculated by multiplying the in situ nutrient concentration of soil samples by the estimated soil loss using RUSLE. The replacement costs of nutrient losses were calculated by multiplying the nutrient loss with the price of available nutrients in urea and diammonium phosphate. The estimate of the RUSLE indicated that the average soil losses in the study watershed were 119 tons $\mathrm{ha}^{-1}$ year $^{-1}$ for non-conserved crop land, 23 tons for conserved farmlands, 23 tons for forest and shrub lands, 19 tons for grazing lands, and 6 tons for plantation forest. The mean soil loss for lower slope classes $(<15 \%)$, middle slope classes (15-30\%) and upper slope classes (>30\%) were 30.11, 48.09 and 57.22 tons $^{-1}$ year $^{-1}$, respectively. The highest losses of total nitrogen (154.7 kg ha year $\left.^{-1}\right)$, available phosphorus $\left(1.84 \mathrm{~kg} \mathrm{ha}^{-1}\right.$ year ${ }^{-1}$ ), and organic matter (1677.9 $\mathrm{kg} \mathrm{ha}^{-1}$ year $\left.^{-1}\right)$ were obtained from non-conserved cropland. Conversely, the lowest values of the same parameters were registered from the land covered with plantation forest. Comparing slope classes for non conserved cropland, organic matter and nutrient losses were higher in upper slope classes followed by middle and lower ones. The replacement cost of available $\mathrm{N}$ and available $\mathrm{P}$ for non-conserved cropland, conserved cropland, forest/shrub lands, grazing lands and plantations were 121.22, 36.41, 27.09, 32.22 and 13.10 Birr ha $^{-1}$ year $^{-1}$, respectively (1USD = 19 Birr); and the weighted mean replacement cost in the watershed was estimated to be 98.1 Birr ha $^{-1}$ year $^{-1}$ which is about $20 \%$ of the cost of fertilizer applied per individual farmers in the watershed. From the study it was possible to conclude that conversion of forest lands and plantation forests to cropland causes serious soil and nutrient losses. Construction of conservation structures on cropland, however, will reduce soil and nutrient losses. To halt soil and nutrient loss and ensure sustainable land management and agricultural development in the Harfetay watershed and similar watersheds, policy and development interventions including increasing awareness of farmers on of soil and nutrient losses, enforcing land use policies and expanding bio-physical soil conservation practices are required.
\end{abstract}

Keywords: slope class, water erosion, soil loss, nutrient loss, nutrient replacement cost, harfetay watershed

\section{Introduction}

Ethiopia is endowed with wealth of biophysical resources including rich biodiversity, relatively fertile soils, and huge fresh water resources. This rich natural resource base has been serving as the foundation for agricultural development and meeting the basic needs of millions of rural people in the country (Gete et al., 2006). Agriculture accounts for about $45.5 \%$ of GDP, $85 \%$ of the employment opportunity and $94 \%$ of Ethiopia's export (NBE, 2002). However, the productivity of that economy is being seriously eroded by unsustainable land management practices in crop and animal feed production systems (Berry, 2003). The Ethiopian rural environment has suffered an accelerating de-vegetation leading to diminishing soil fertility, enhanced soil erosion, increased severity of the impact of drought, and a further reduction in the ability to produce food and other biological resources (Aster, 2004). 
Soils are the main terrestrial reservoir for organic matter and nutrients like nitrogen and phosphorus. Depletion of soil fertility leads to declining crop yields and a rise in the number of food insecure people (Bojo \& Cassells, 1995; Woldeyesus \& Chilot, 2002). Soil and nutrient loss has been identified as an important factor controlling productivity (Seastedt et al., 1991). Soil nutrient mining is caused due to net nutrient extraction by crops and loss along with eroded soil in the highlands of Ethiopia. EFAP (1994) estimated that about 1.9 to 3.5 billion tons of fertile topsoil are being washed away each year from Ethiopian highlands mainly as the ultimate result of deforestation.

Stoorvogel and Smaling (1990) reported that estimate of nutrient losses from soils of the highlands of Ethiopia is in excess of $80 \mathrm{~kg} \mathrm{ha}^{-1}$ of $\mathrm{N}, \mathrm{P}_{2} \mathrm{O}_{5}$ and $\mathrm{K}_{2} \mathrm{O}$ from cultivated lands whereas addition of nutrient through fertilizer applications amounts to only $10 \mathrm{~kg} /$ ha (i.e. $12 \%$ of the loss). Due to this reason, land degradation greatly affects agricultural productivity (Demel Teketay, 2005). Chilot and Hassan (2010) also reported that in 1990 alone, decrease of soil depth caused by erosion was estimated to be $3.5 \mathrm{~mm}$ to $8.0 \mathrm{~mm}$ resulting in a grain production loss of 57,000 to 128,000 tons. Taking in to account the per-capita consumption of cereals in sub-Saharan Africa range from 39.7 - 134.1 kg per annum (FAO, 1987), the grain production lost due to land degradation in 1990 would have been sufficient to feed more than four million people.

To increase yield of crops, many farmers in the highlands of Northwestern Ethiopia use inorganic fertilizers. Fertilizer (DAP and Urea) imports have shown an increasing trend for the past four decades. In the years between 1996 and 2011, imported volumes increased from 100,000 tons to over 500,000 tons (Addis-Fortune, 2011). Even though in recent years the use of fertilizer has increased in Ethiopia, there is evidence that most farmers are not adequately compensating for the loss of soil nutrients caused by erosion and crop uptake (Mulat, 1996). Evidences are, however, very few to generate development and policy recommendations. Hence, generating data on the level of soil and nutrient losses from different land uses and slope classes helps to solidify facts that will be used to advise policy makers and development practitioners on the intervention mechanisms. However, limited information is available in northwestern Ethiopia. This particular study was, therefore, conducted in Harefetay watershed, Libokemkem woreda, South Gondar Zone of northwestern Ethiopia. Hence, the major objective of this research was is to estimate soil, nutrient and organic matter losses and calculate the replacement costs of major nutrients lost by erosion from the watershed.

\section{Materials and Methods}

\subsection{Description of the Study Area}

Harfetay watershed is found near Yifag town in Libokemkem District, South Gondar Zone, Amhara National Regional State (ANRS) in northwestern Ethiopia (Figure 1). The watershed falls within an altitudinal range of 1880 and 2100 m.a.s.l. The ten years mean maximum and minimum temperatures were $27.9^{\circ} \mathrm{C}$ and $11.1^{\circ} \mathrm{C}$, respectively (Libokemkem Woreda Office of Agriculture, 2009). Similarly, the mean annual total rainfall range between 900 and $1400 \mathrm{~mm}$ with uni-modal distribution that occurs from June to September (Begashaw, 2005). The topography of the area varies from slightly flat land to sloppy land with a slope ranging from 5 to $60 \%$. The watershed encompasses different land uses such as cropland ( $215 \mathrm{ha})$, forest/shrub land ( $23 \mathrm{ha})$, plantation forest ( $5.5 \mathrm{ha}$ ), grazing lands ( $8.9 \mathrm{ha}$ ) and rock outcrops ( $1.3 \mathrm{ha}$ ). The cultivated land covers $87 \%$ of the watershed and the majority of it is not treated with physical conservation measures.

\subsection{Soil Samples Collection and Analysis}

After a reconnaissance survey guided by the topo-map of the study area was conducted, 65 soil samples from five land use types including non-conserved cropland, conserved farmlands, forest, grazing land and plantation forest were collected from a transect at a grid of every $100 \mathrm{~m}$ along the slope and every $250 \mathrm{~m}$ across the slope from 15 $\mathrm{cm}$ soil depth using system outlined in Yao et al. (2010). GPS points were recorded to locate the sampling locations (Figure 2). The collected soils were analyzed for organic matter (OM) following Walkley and Black procedures (Nelson \& Sommers, 1982); total N (TN) using Kjeldhal method (Bremner \& Mulvaney, 1982); and available P (AP) was estimated using the Olsen method (Olsen \& Sommers, 1982). Soil pH was determined in 1: 2.5 soil water ratio. The mean nutrient availability indices from each land use type and slope classes were used to estimate the nutrient loss with eroded soil from the watershed. 


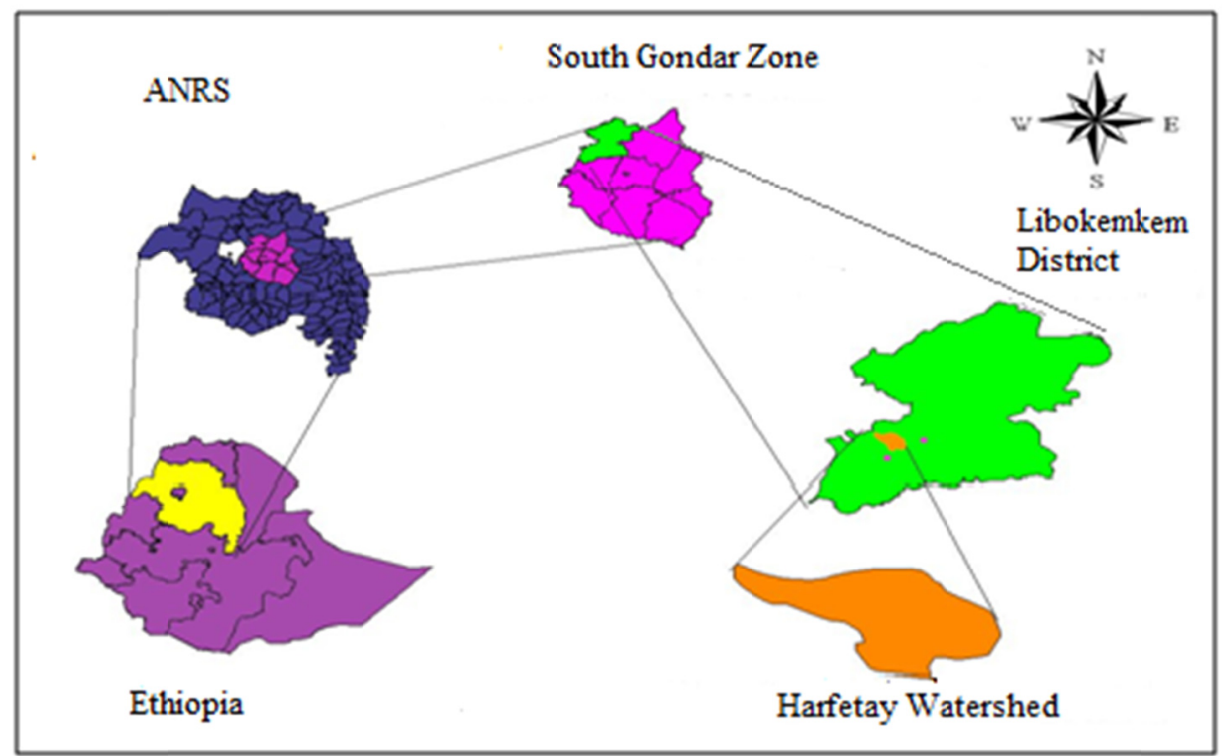

Figure 1. Location of the study area

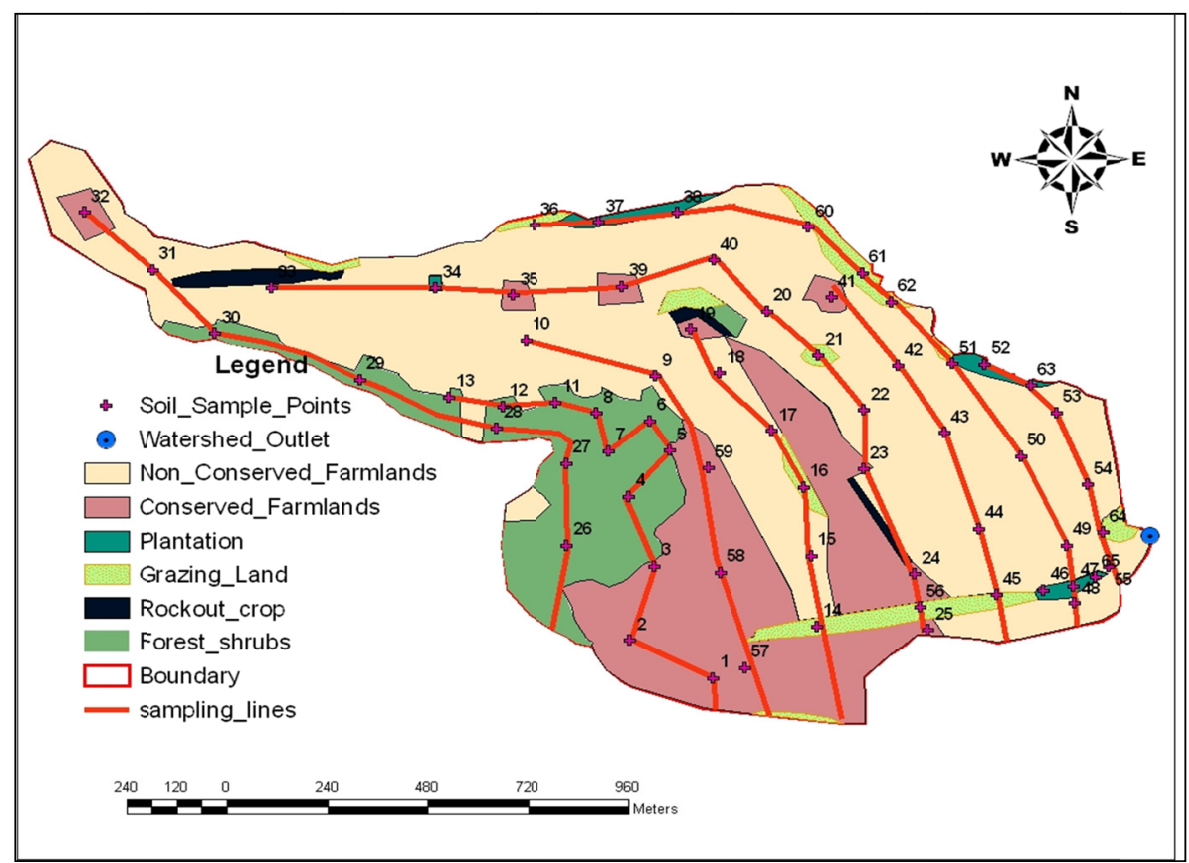

Figure 2. Soil sampling lines, soil sample points and land use types

\subsection{Estimation of Soil Loss}

To estimate the soil loss in the watershed, land use types were delineated into appropriate size using natural barriers. Annual soil losses in the form of runoff from different land uses and slope classes of the watershed were estimated using the Revised Universal Soil Loss Equation (RUSLE) developed by Wischmeier and Smith (1978) and calibrated for Ethiopia by Hurni (1985) which is

$$
\mathrm{A}=\mathrm{R} * \mathrm{~K} * \mathrm{~L} * \mathrm{~S} * \mathrm{C} * \mathrm{P}
$$

Where $\mathrm{A}$ is the estimated soil loss $\left(\mathrm{t} \mathrm{ha}^{-1} \mathrm{yr}^{-1}\right)$; $\mathrm{R}$ is the rainfall erosivity factor; $\mathrm{K}$ is the soil erodibility factor; $\mathrm{L}$ is the slope length factor; $\mathrm{S}$ is the slope gradient factor; $\mathrm{C}$ is the land cover factor and $\mathrm{P}$ is the management practice factor. 
The erosivity factor (R) was extrapolated from a tabular value developed by Wishmeiere and Smith (1978) adapted by Hurni (1985) for Ethiopian conditions based on the long term mean annual rainfall $(\mathrm{P})$ as $\mathrm{R}=-8.12+[0.562 \mathrm{x}$ $P]$. The "R" value for the average rainfall of the watershed $(1320.5 \mathrm{~mm})$ was found to be 734 . To determine "K", a systematic observation on soil color of watershed was carried out, based on the approach described in Hurni (1985). Hence, "K" values for black, brown, red and yellow soils are $0.15,0.20,0.25$ and 0.30 , respectively. The tabular values for the slope length factor (L) and slope gradient factor (S) were determined from the distance between two points along the slope and slope gradients in percent. The land cover (C) represents the ratio of soil loss under a given land cover/land use to that of the bare soil (Morgan, 2005) or continuous fallow (Wischmeier \& Smith, 1978). Assessment of the type of land use-cover was made separately for each land unit and the corresponding land cover factor was obtained from Hurni (1985). The major crop covers found in the watershed were cereals and pulses. As a result 0.15 was used as crop factor for agricultural lands. Moreover, the land cover factor for forests and bush lands were taken as 0.01 , for plantations as 0.01 and for grazing lands as 0.05 .

The management practice factor $(\mathrm{P})$ gives the ratio between the soil loss expected for a certain soil conservation practice to that with up-and down-slope ploughing (Wischmeier \& Smith, 1978). Specific cultivation practices affect erosion by modifying the flow pattern and direction of runoff and by reducing the amount of runoff (Renard \& Foster, 1983). In areas where there is terracing, runoff speed could be reduced with increased infiltration, ultimately resulting in lower soil loss and sediment delivery. Values for this factor were assigned considering local management practices and based on values suggested in Hurni (1985). Hence "P" values are 1.0 for ploughing up and down, 0.9 for ploughing on contour, 0.80 for strip cropping, $40 \%$ stone cover, intercropping and grass strips; 0.70 for dense intercropping; 0.60 for applied mulch, and 0.50 for $80 \%$ stone cover.

\subsection{Estimation of Nutrient Loss and Replacement Cost}

Nutrient concentrations in soil are often expressed in terms of $\mathrm{kg} \mathrm{ha}^{-1}$ for a given depth within the soil profile. To determine the nutrient loss, the estimated soil amount being lost and nutrient concentration must be known or have to be estimated (Marx et al., 1999). Since the watershed does not have gauging station and RUSLE is estimating soil loss without taking actual measurements, nutrient and organic matter losses were determined by multiplying the in-situ nutrient and organic matter contents of soil in different land use systems and three slope classes by the amount of soil loss from each land use types and slope classes estimated by RUSLE.

Since the soil eroded by water largely contains finer particles and top soil compared to soils that remain in situ, the eroded soil is expected to have higher amount of nutrients. Therefore, the estimate in this procedure is expected to underestimate the nutrient losses. However, this approach still serves the purpose for estimating nutrient losses that can serve as an input to policy and development recommendations. The replacement costs of available nitrogen and phosphorus lost from the watershed along the soil eroded by water from different land use types (LUTs) and slope classes were estimated by multiplying the estimated amount of nutrient lost with the eroded soil by the cost of equivalent amounts of available nutrients in urea and dimammonium phosphate (DAP) fertilizers.

The process of $1 \mathrm{~kg}$ of $\mathrm{N}$ and $\mathrm{P}$ were calculated using the following formulas:

Price of $1 \mathrm{~kg}$ available $\mathrm{N}=$ total price of applied $\mathrm{N}$ fertilizer/Nutrient content of fertilizer applied

Price of $1 \mathrm{~kg}$ available $\mathrm{P}=$ the price of $100 \mathrm{~kg}$ of DAP * (price of $1 \mathrm{~kg}$ of $\mathrm{N} * \mathrm{~N}$ content in DAP)/AP content in DAP

\subsection{Statistical Analysis}

One way analysis of variance (ANOVA) was used to detect differences among the land use types and slope classes. When ANOVA test was found to be statistically significant $(\mathrm{p} \leq 0.05)$, further analysis of mean separation was carried using Duncan's Multiple Range Test (DMRT) using Duncan's multiple range test (DMRT) available in SPSS version 16 software.

\section{Results and Discussion}

\subsection{Determination of in Situ Soil Physico-Chemical Properties}

Measurements made to analyze the nutrient contents indicated that there were significant differences $(\mathrm{p}<0.05)$ in total nitrogen, available nitrogen, available phosphorus, organic matter, bulk density and $\mathrm{pH}$ among the various land use types and slope classes (Table 12). Higher level of TN, and AP were registered from plantation forests followed by grazing lands and forest/shrub lands and the lowest levels were found in non-conserved croplands. Based on classifications of Landon (1991), the total N contents can be categorized as low in non conserved and conserved croplands and medium in the other land uses. The organic matter contents are also very low in non conserved as well as conserved croplands; and low in other land uses. However, the available P contents can be 
grouped as medium in forest and shrub lands and high in other land uses. The highest bulk density was registered from non-conserved croplands where us the lowest was found from forest and shrub lands. Soil pH was significant difference $(\mathrm{p}<0.05)$ among different land use types. The presence of low $\mathrm{pH}$ value in forest lands and shrub lands could be due to high OM in forest and shrub lands. Its decomposition leads to the formation of organic acids and leaching of basic cations which lowers the $\mathrm{pH}$ value.

Table 1. Chemical soil characteristics for land use types and slope classes

\begin{tabular}{lccccc}
\hline Land use Types & $\mathrm{TN}(\%)^{*}$ & $\mathrm{OM}(\%)^{*}$ & $\mathrm{AP}\left(\mathrm{mg} \mathrm{kg}^{-1}\right)^{*}$ & $\mathrm{BD}\left(\mathrm{gm} \mathrm{cm}^{-3}\right)^{*}$ & $\mathrm{pH}\left(1: 2.5 \mathrm{H}_{2} \mathrm{O}\right)^{*}$ \\
\hline Non conserved cropland & $0.13^{\mathrm{b}}$ & $1.41^{\mathrm{b}}$ & $15.43^{\mathrm{bc}}$ & $1.34^{\mathrm{a}}$ & $6.4^{\mathrm{a}}$ \\
Conserved cropland & $0.15^{\mathrm{b}}$ & $1.47^{\mathrm{b}}$ & $21.63^{\mathrm{b}}$ & $1.32^{\mathrm{a}}$ & $6.1^{\mathrm{ab}}$ \\
Forest and Shrub lands & $0.21^{\mathrm{a}}$ & $2.80^{\mathrm{a}}$ & $9.46^{\mathrm{c}}$ & $1.08^{\mathrm{b}}$ & $5.9^{\mathrm{b}}$ \\
Grazing lands & $0.22^{\mathrm{a}}$ & $2.51^{\mathrm{a}}$ & $20.86^{\mathrm{b}}$ & $1.13^{\mathrm{b}}$ & $6.2^{\mathrm{ab}}$ \\
Plantation forest & $0.24^{\mathrm{a}}$ & $2.61^{\mathrm{a}}$ & $29.86^{\mathrm{a}}$ & $1.29^{\mathrm{a}}$ & $6.3^{\mathrm{ab}}$ \\
\hline Slope classes in non-conserved cropland & & & & \\
Lower slope class (<15\%) & $0.17^{\mathrm{a}}$ & $1.89^{\mathrm{a}}$ & $20.88^{\mathrm{a}}$ & $1.30^{\mathrm{a}}$ & $6.4^{\mathrm{a}}$ \\
Middle slope class (15-30\%) & $0.17^{\mathrm{a}}$ & $2.06^{\mathrm{a}}$ & $18.16^{\mathrm{ab}}$ & $1.22^{\mathrm{ab}}$ & $5.9^{\mathrm{a}}$ \\
Upper slope class (>30\%) & $0.22^{\mathrm{a}}$ & $2.47^{\mathrm{a}}$ & $11.48^{\mathrm{b}}$ & $1.10^{\mathrm{b}}$ & $5.8^{\mathrm{b}}$ \\
\hline
\end{tabular}

TN: total N; OM: organic matter; AP: available phosphorus; BD: bulk density.

* Means in a column for land use types and slope classes followed by the same letter(s) are not significantly different at $\mathrm{p}<0.05$.

\subsection{Soil Loss and Equivalent Nutrient Removal From Different Land Use Types and Slope Classes}

Soil erosion was estimated to be the highest in non-conserved farmlands (about 119 tons $^{-1}$ year $^{-1}$ ) because of cultivation of rolling mountains and poor conservation practices. . The major parts of the cultivated farmlands do not have conservation practices although most of the area is found in the steeper slopes naturally prone to soil losses by water erosion. The results obtained in this study were in many of the land uses and slope classes higher than previous reports. Berry (2003) estimated that soil loss by water erosion croplands range from 3.4 to 84.5 tons $\mathrm{ha}^{-1}$ year $^{-1}$ with a mean of 32 tons $\mathrm{ha}^{-1}$ year $^{-1}$. In the conserved farmlands, with construction of stone terraces along the contour with a mean distance of $15 \mathrm{~m}$, the soil loss was estimated to be 23 tons ha $^{-1}$ year ${ }^{-1}$. This soil loss is still double the acceptable limit of soil loss of 12 tons $^{-1}$ year $^{-1}$ (Ermias et al., 2009) and far exceeds the mean annual rate of soil formation which is 6 tons $^{-1}$ year $^{-1}$ (Hurni, 1995).

The estimated mean soil loss in forest and shrub lands was 23 tons $^{-1} \mathrm{year}^{-1}$. Even though vegetation cover should reduce erosion, farmers still cut trees and shrubs for fuel wood for household energy source and income generation which reduces the canopy cover exacerbating erosion. As reported in Morgan (2005), it is apparent that living and dead plant biomasses reduce soil erosion by intercepting and dissipating raindrops energy that would detach soil particles from the soil aggregate. Aboveground foliage slows the velocity of water running over the soil decreasing the volume of water and soil lost in surface runoff. Plant roots also physically bind particles, thus stabilizing the soil and increasing its resistance to erosion. Plant roots also enhance water conservation by creating pores in the soil surface that enable water to enter easily into the soil matrix at the expenses of the surface runoff which leads to soil erosion. The uptake of water by plant roots also somehow deplete soil water content and thereby further increases infiltration rates (Bezuayehu et al., 2002). Even though the estimated soil loss in this forest and shrub lands is 19 tons ha $^{-1}$ year $^{-1}$, which is less than conserved croplands, grazing lands and non-conserved croplands, this is still by far more than the acceptable limit of soil loss.

The mean annual soil loss estimated from grazing lands was 19 tons $^{-1} \mathrm{y}^{-1}$ year $^{-1}$, which is higher than the acceptable or tolerance limit of soil loss. Mean soil loss in plantations is estimated to be 6 tons ha $^{-1}$ year ${ }^{-1}$, which is the lowest soil loss estimated in the watershed. Generally, the mean soil loss was found different $(\mathrm{p}<0.05)$ among land use types except for the soil loss in conserved croplands and grazing lands. The weighted mean annual soil loss of the watershed estimated using RUSLE was found to be 84 tons $\mathrm{ha}^{-1}$ year $^{-1}$. 
The mean value of soil loss in higher slope classes was higher than the lower slope classes which was expected since soil erosion increases with an increase of slope steepness associated with an augmentation of the velocity of the runoff. However, there was no difference which could be due to forest and shrub land cover on the upper parts of the watershed and non-conserved croplands on the lower slope classes. Fozi (2000) also reported that slope alone does not significantly influence the amount of soil loss. It is apparent that soil loss is a function of different factors like erosivity, soil erodibility, slope length, slope gradient, land cover and land management practice that are mentioned in the RUSLE (Hurni,1985).

The losses of TN, AP and OM all were found different $(\mathrm{p}<0.05)$ among LUTs. Total N loss was $153.63 \mathrm{~kg} \mathrm{ha}^{-1}$ year $^{-1}$ from non-conserved croplands, 34.5 from conserved croplands, 48.3 from forest and shrub lands, and 14.4 from grazing lands and plantations (Table 2). The highest loss of TN occurred in non-conserved croplands followed by grazing lands and the least in the plantations which could be directly related to the amount of OM lost from the watershed along with the soil. The AP loss in the watershed was $1.84 \mathrm{~kg} \mathrm{ha}^{-1}$ year $^{-1}$ from non-conserved croplands, $0.50 \mathrm{~kg} \mathrm{ha}^{-1}$ year ${ }^{-1}$ from conserved croplands, $0.22 \mathrm{~kg} \mathrm{ha}^{-1}$ year ${ }^{-1}$ from forest and shrub lands, $0.40 \mathrm{~kg}$ $\mathrm{ha}^{-1}$ year ${ }^{-1}$ from grazing lands and $0.18 \mathrm{~kg} \mathrm{ha}^{-1}$ year $^{-1}$ from plantations. The highest loss of AP was found in non-conserved croplands similar to other soil parameters considered followed by conserved croplands and the least occurred in forest and shrub lands. Stoorvogel and Smaling (1990) also reported that Ethiopia had among the highest rates of nutrient depletion in sub-saharan Africa with nitrogen loss reaching $30 \mathrm{~kg} \mathrm{ha}^{-1}$ and phosphorus loss of $15-20 \mathrm{~kg} \mathrm{ha}^{-1}$. Bojo and Cassells (1995) similarly reported that an estimated gross financial losses due to land degradation reaching 106 million US\$ year ${ }^{-1}$. The loss of OM in the watershed was $1676.9 \mathrm{~kg} \mathrm{ha}^{-1}$ year $^{-1}$ from $^{-1}$ non-conserved croplands, $338.10 \mathrm{~kg} \mathrm{ha}^{-1}$ year $^{-1}$ from conserved croplands, $644.16 \mathrm{~kg} \mathrm{ha}^{-1}$ year $^{-1}$ from forest and shrub lands, $476.90 \mathrm{~kg} \mathrm{ha}^{-1}$ year ${ }^{-1}$ from grazing lands and $156.60 \mathrm{~kg} \mathrm{ha}^{-1}$ year $^{-1}$ from plantations (Table 2). Similarly, the same parameters were significantly different $(\mathrm{p}<0.05)$ among slope classes in the non-conserved croplands (Table 2). More TN and AP losses were observed from the middle slope class (15-30\%) than the upper slope class $(>30 \%)$ which could be due to the low nitrogen and phosphorus fertilizers additions in these lands which lowered the in situ nutrient content.

Table 2. Soil, nutrient and OM losses from different LUT, management practices and slope classes

\begin{tabular}{lcccc}
\hline \multirow{2}{*}{ Land Use Types } & \multirow{2}{*}{ Soil Loss (tones ha $\left.\mathrm{hear}^{-1}\right)$} & \multicolumn{4}{c}{$\left(\mathrm{kg} \mathrm{ha}^{-1} \mathrm{year}^{-1}\right)^{*}$} \\
\cline { 3 - 5 } & & $\mathrm{TN}$ & AP & OM \\
\hline Non conserved croplands & $119.0 \mathrm{a}$ & $154.7^{\mathrm{a}}$ & $1.84^{\mathrm{a}}$ & $1677.9^{\mathrm{a}}$ \\
Conserved croplands & $23.0^{\mathrm{b}}$ & $34.5^{\mathrm{bc}}$ & $0.50^{\mathrm{b}}$ & $338.10^{\mathrm{bc}}$ \\
Forest and shrub lands & $23.0^{\mathrm{b}}$ & $48.3^{\mathrm{b}}$ & $0.22^{\mathrm{c}}$ & $644.16^{\mathrm{b}}$ \\
Grazing lands & $19.0^{\mathrm{c}}$ & $41.8^{\mathrm{b}}$ & $0.40^{\mathrm{b}}$ & $476.90^{\mathrm{b}}$ \\
Plantation & $6.0^{\mathrm{d}}$ & $14.4^{\mathrm{c}}$ & $0.18^{\mathrm{c}}$ & $156.60^{\mathrm{c}}$ \\
\hline Slope classes non- conserved croplands & & & & \\
Lower slope class (<15\%) & $51.19^{\mathrm{c}}$ & $69.40^{\mathrm{b}}$ & $0.63^{\mathrm{b}}$ & $769.08^{\mathrm{c}}$ \\
Middle slope class (15-30\%) & $81.75^{\mathrm{b}}$ & $80.79^{\mathrm{a}}$ & $0.87^{\mathrm{a}}$ & $990.65^{\mathrm{b}}$ \\
Upper slope class (>30\%) & $125.88^{\mathrm{a}}$ & $53.85^{\mathrm{c}}$ & $0.66^{\mathrm{b}}$ & $1413.33^{\mathrm{a}}$ \\
\hline
\end{tabular}

* Means in a column for land use types and slope classes followed by the same letter are not different at $\mathrm{p}<0.05$.

\subsection{Nutrient Replacement Costs in Different Land Use Types and Slope Classes}

It is apparent that organic matter, micro and macro nutrients are getting lost with soil lost in erosion. However, it is easier to quantify the replacement costs of most of the nutrients but not that of organic matter since its costs are not known. The fertilizer types used in the study area are urea and DAP which are the only fertilizers imported and distributed in the country. The price of fertilizers was 885 and 1172 Birr for $100 \mathrm{~kg}$ of urea and DAP, respectively in 2011 (1US\$ $=19.00$ Birr). The average amount of fertilizers used by individual farmers in the watershed is 25 $\mathrm{kg}$ of urea and $25 \mathrm{~kg}$ of DAP per household. It is found that farmers use these fertilizers for major crops like maize (Zea mays), wheat (Triticum aestivum) and teff (Eragrostis tef). The cost of $1 \mathrm{~kg}$ of available nitrogen in urea (46\% $\mathrm{N})$ and DAP $(18 \% \mathrm{~N})$ was 19.24 Birr and the cost of $1 \mathrm{~kg}$ of AP in DAP was 41.29 Birr. DAP contains $18 \%$ nitrogen and $20 \%$ available phosphorus (AP) (Table 3). 
Table 3. Costs of fertilizers applied and prices of nitrogen and available phosphorous in the watershed

\begin{tabular}{|c|c|c|c|c|c|c|c|c|c|}
\hline $\begin{array}{l}\text { Fertilizer } \\
\text { types }\end{array}$ & $\begin{array}{l}\text { Types of } \\
\text { Nutrient }\end{array}$ & Grade & $\begin{array}{l}\text { Nutrient } \\
\text { Content } \\
(\%)\end{array}$ & $\begin{array}{l}\text { Mean fertilizer } \\
\text { use by farmers } \\
(\mathrm{kg})\end{array}$ & $\begin{array}{l}\text { Price of } \\
\text { Fertilizer } \\
\text { applied } \\
\left(\text { Birr kg }^{-1}\right)\end{array}$ & $\begin{array}{l}\text { Cost } \\
\text { fertilizers } \\
\text { applied } \\
\text { (Birr) }\end{array}$ & & $\begin{array}{l}\text { Nutrient content of } \\
\text { fertilizers applied } \\
(\mathrm{kg})\end{array}$ & $\begin{array}{l}\text { Price of } \\
\text { nutrients } \\
\left(\text { Birr kg }^{-1}\right)\end{array}$ \\
\hline rea & $\mathrm{AN}$ & $46-0-0$ & 46 & 25 & 8.85 & 221.25 & & 11.5 & 19.24 \\
\hline DAP & AN \&AP & $18-46-0$ & $\begin{array}{l}18 \mathrm{AN} \& \\
20 \mathrm{AP}\end{array}$ & 25 & 11.72 & 293.00 & & $4 \mathrm{~N} \& 5 \mathrm{P}$ & $\begin{array}{l}19.24 \text { for } \mathrm{AN} \& \\
41.29 \text { for } \mathrm{AP}\end{array}$ \\
\hline
\end{tabular}

The mean replacement costs of $\mathrm{N}$ and AP were found significantly different $(\mathrm{p}<0.05)$ among LUTs with the highest replacement cost in the non-conserved croplands and the lowest in plantations (Table 4). The weighted mean replacement cost of $\mathrm{AN}$ and $\mathrm{AP}$ nutrients lost in terms of fertilizer cost from different land use types was estimated to be 98.1 Birr (Table 4) which was higher than reported by Nigussie Haregeweyn et al. (2007) for Tigray Region. The value of nutrient replacement cost from non conserved croplands was the highest loss compared to other land uses which is $121.23 \mathrm{Birr} \mathrm{ha}^{-1} \mathrm{year}^{-1}$. The second largest replacement cost estimated to occur was in conserved croplands with $36.41 \mathrm{Birr} \mathrm{ha}^{-1}$ year $^{-1}$ followed by grazing lands with $32.22 \mathrm{Birr}^{-1} \mathrm{year}^{-1}$. Forest and shrub lands and plantations had the lowest replacement cost of nutrients estimated with 27.09 and 13.10 Birr, respectively.

The weighted mean replacement costs of AN and AP are 34.01 and 42.31 Birr $^{-1}{ }^{-1}$ year ${ }^{-1}$, respectively. The weighted mean AN and AP nutrient loss from the watershed (98.1 Birr ha ${ }^{-1}$ year $^{-1}$ ) is equivalent to $20 \%$ of mean cost paid for fertilizer by individual farmers in the watershed. But the replacement costs of nutrients lost from non-conserved croplands comprises $24 \%$ of fertilizer added by individual farmers. If the weighted means loss replacement cost is extrapolated to the high lands of Amhara region $\left(161,828.4 \mathrm{~km}^{2}\right.$ ) (Begashaw Molla, 2005) and the highlands of Ethiopia $\left(4.48 \times 10^{5} \mathrm{~km}^{2}\right.$ ) (Nigussie et al., 2007) will be 1.59 and 4.39 billion Birr, respectively. The inclusion of TN and OM and other nutrients losses as well as the deterioration in soil physical properties raises the cost to a much higher level (Nigussie et al., 2007). Bojo and Cassells (1995) also reported estimated gross financial losses at 106 million US\$ year ${ }^{-1}$ due to land degradation. The mean replacement cost of AN and AP increases when we go from lower slope class to middle and upper slope classes.

Table 4. Mean Nutrient loss and replacement costs of AN and AP

\begin{tabular}{|c|c|c|c|c|c|}
\hline \multirow{2}{*}{ LUT } & \multicolumn{2}{|l|}{ AN } & \multicolumn{2}{|l|}{$\mathrm{AP}$} & \multirow{2}{*}{$\begin{array}{l}\text { Total nutrient replacement cost } \\
\left(\text { Birr ha }^{-1} \text { year }^{-1}\right)\end{array}$} \\
\hline & $\mathrm{kg} \mathrm{ha}^{-1}$ year $^{-1}$ & Birr ha $^{-1}$ year $^{-1}$ & $\mathrm{~kg} \mathrm{ha}^{-1}$ year $^{-1}$ & Birr ha $^{-1}$ year $^{-1}$ & \\
\hline Non conserved croplands & $2.36^{\mathrm{a}}$ & $45.40^{\mathrm{a}}$ & $1.84^{\mathrm{a}}$ & $75.82^{\mathrm{a}}$ & $121.22^{\mathrm{a}}$ \\
\hline Conserved croplands & $0.82^{\mathrm{b}}$ & $15.87^{\mathrm{b}}$ & $0.50^{\mathrm{b}}$ & $20.54^{\mathrm{b}}$ & $36.41 b^{b}$ \\
\hline Forest and shrub lands & $0.94^{\mathrm{b}}$ & $18.10^{\mathrm{b}}$ & $0.22^{\mathrm{c}}$ & $8.98^{\mathrm{c}}$ & $27.09^{\mathrm{b}}$ \\
\hline Grazing lands & $0.82^{\mathrm{b}}$ & $15.85^{\mathrm{b}}$ & $0.40^{\mathrm{b}}$ & $6.36^{\mathrm{c}}$ & $32.22^{b}$ \\
\hline Plantations & $0.30^{c}$ & $5.70^{\mathrm{c}}$ & $0.18^{\mathrm{c}}$ & $7.40^{\mathrm{c}}$ & $13.10^{\mathrm{c}}$ \\
\hline Weighted mean replacement cost & & 34.01 & & 42.31 & 98.1 \\
\hline \multicolumn{6}{|c|}{ Slope class in non- conserved croplands } \\
\hline Lower slope class $(<15 \%)$ & $0.88^{\mathrm{b}}$ & $16.93^{\mathrm{b}}$ & $0.63^{\mathrm{a}}$ & $25.95^{\mathrm{b}}$ & $42.39^{\mathrm{c}}$ \\
\hline Middle slope class (15-30\%) & $2.36^{\mathrm{a}}$ & $45.33^{\mathrm{a}}$ & $0.87^{\mathrm{a}}$ & $36.06^{\mathrm{a}}$ & $81.39^{\mathrm{a}}$ \\
\hline Upper slope class ( $>30 \%)$ & $2.16^{\mathrm{a}}$ & $41.52^{\mathrm{a}}$ & $0.66^{\mathrm{a}}$ & $27.12^{\mathrm{b}}$ & $68.64^{\mathrm{b}}$ \\
\hline
\end{tabular}

* Means in a column for land use types or slope classes followed by the same letter are not different at $\mathrm{p}<0.05$.

\section{Conclusions and Recommendations}

The study showed that the mean soil loss together with the nutrients and organic matter in it due to water erosion is very high on farmlands devoid of vegetation. Continuous soil losses of top soil leads to the occurrence of unproductive subsoil and rock outcrops which depress yields and increase food insecurity for the local community. 
Furthermore, new forest and shrub lands found on the steep slopes will be cleared for their livelihood. Therefore, there is urgent need of strengthening soil conservation practices in existing farmlands to prevent expansion of crop production to forest lands and steep slopes which otherwise aggravates soil loss rate and flood hazards. In fact, extensive work on awareness of the paramount importance of soils conservations practices in slope lands of Northeastern Ethiopia should be given high priority. Moreover, enforcement of the land use policy of Amhara National Regional State is critically required for sustainable natural resources management.

\section{Acknowledgments}

This paper is based on work conducted within the framework of the Swiss National Centre of Competence in Research (NCCR) North-South: Research Partnerships for Mitigating Syndromes of Global Change.

\section{References}

Addis-Fortune. (2011). Import of 450,000tn of fertilizer arrive next week. Retrieved from http://www.addisfortune.com/Import $\% 20 \mathrm{of} \% 20450,000 \mathrm{tn} \% 20$ Fertilizer $\% 20$ to $\% 20$ Arrive $\% 20 \mathrm{Next} \% 20$ Wee k.htm

Aster, D. (2004). Use of Geospatial Technologies for Environmental Protection in Ethiopia. Environmental Protection Authority. United Nations/European Space Agency/Sudan. Remote Sensing Workshop on the Use of Space Technology for Natural Resources Management Environmental Monitoring and Disaster Management. April 4-8, 2004 Sudan, Khartoum.

Begashaw, M. (2005). Evaluation of Rainwater Harvesting Systems In Amhara Region: A Case Study In Libokemkem Woreda. A Thesis Submitted to the College of Agriculture, Department of Agricultural Engineering, School of Graduate Studies. In Partial Fulfillment of the Requirements for the Degree of Master of Science in Soil and Water Engineering (Soil and Water Conservation Engineering). Alemaya University.

Berry, L. (2003). Land Degradation in Ethiopia: Its Extent and Impact. Commissioned by the GM.

Bezuayehu, T., Gezahegn, A., Yigezu, A., Jabbar, M. A., \& Paulos, D. (2002). Nature and causes of land degradation in the Oromiya Region: A review. International Livestock Research Institute. Ethiopian Agricultural Research Organization. Oromiya Natural Resources Development and Environmental Protection Authority. Socioeconomics and Policy Research Working Paper No. 36.

Bojo, J., \& Cassells, D. (1995). Land degradation and rehabilitation in Ethiopia: a reassessment. AFTES Working Paper No. 17. The World Bank, Washington DC.

Bremner, J. M., \& Mulvaney, C. S. (1982). Nitrogen-total. In A. L. Page (Ed.), Methods of Soil Analysis, Part 2: Chemical and Microbiological Properties (pp. 595-624). Agronomy 9. Madison, Wisconsin.

Chilot, Y., \& Hassan, R. M. (2010). Social costs and incentives for optimal control of soil nutrient depletion in the central highlands of Ethiopia. Agricultural Systems, 103, 153-160. http://dx.doi.org/10.1016/j.agsy.2009.12.002

Demel, T. (2005). Deforestation, Wood Famine, and Environmental Degradation in Ethiopia's Highland Ecosystems: Urgent Need for Action. Michigan State University. All rights reserved. Northeast African Studies, 8(1), 53-76.

Ethiopian Forest Action Program (EFAP). (1994). Ethiopian forestry action program: The challenge for development. Addis Abeba, Ethiopia.

Ermias, T., Dagnachew, L., Belay, S., \& Weldeamlak, B. (2009). Basis of Soil Erosion Risk in the source region of the Blue Nile river using RUSLE model, Remote Sensing and GIS: case study in the Muga watershed. In F. Hagos, M. Kassie, T. Woldegiorgis, Y. Mohammednur, \& Z. Gebreegziabher (Eds.), Proceedings of Collaborative National Workshop on Sustainable Land Management Research and Institutionalization of Future Collaborative Research (pp.50-65). August 8-9, 2008. Axum Hotel, Mekelle, Ethiopia.

FAO. (1987). Strategies and requirements for improved production of roots, tubers and plantains. Committee on Agriculture, Sess. 9. Rome, 23 March - I April 1987. Rome.

Fozi, A. M. (2000). The Effect of Slope Steepness on Soil Loss under Natural Rainfall Distribution. Masters thesis, Universiti Putra Malaysia. Retrieved October 22, 2011, from http://psasir.upm.edu.my/10529/

Gete, Z., Menale, K., Pender, J., \& Mahmud, Y. (2006). Stakeholder Analysis for Sustainable Land Management (SLM) in Ethiopia: Assessment of Opportunities, Strategic Constraints, Information Needs, and Knowledge Gaps. 
Hurni, H. (1985). Erosion-productivity systems in Ethiopia. In Proceedings of the Fourth International Conference on Soil Conservation. Venezuela.

Hurni, H. (1995). Simen Mountains Baseline Study - Ethiopia: Intermediate report on the 1994 field expedition. Addis Abeba: Ministry of Natural Resources Development and Environmental Protection.

Landon, J. R. (1991). Booker tropical soil manual: A hand book for soil survey and agricultural land evaluation with tropics and subtropics. Essex, New York: Longman scientific and technical Publishers.

Libokemkem Woreda Office of Agriculture. (2009). Libokemkem, the Development Land of the Renaissance (Amharic version). Trade and development expo week. Addis Zemen.

Marx, E. S., Hart, J., \& Stevens, R. G. (1999). Soil Test Interpretation Guide. Oregon State University Extension Service.

Morgan, R. P. C. (2005). Soil erosion and conservation (3rd ed.). Blackwell science Ltd. A blackwell publishing company.

Mulat, D. (1996). Constraints to efficient and sustainable use of fertilizers in Ethiopia'. In M. Demeke, W. Amha, T. Zegeye, S. Bellete, \& Simeon Ehui (Eds.), Sustainable Intensification of Agriculture in Ethiopia (pp. 242-266). Proceedings of the Second Conference of the Agricultural Economics Society of Ethiopia, Agricultural Economics Society of Ethiopia, Addis Ababa.

NBE. (2002). Annual Report for the year 200/01. Economic Research Department of National Bank of Ethiopia, Addis Ababa.

Nelson, D. W., \& Sommers, L. E. (1982). Total carbon, organic carbon and organic matter (pp. 539-579). In A. L. Page (Ed.), Methods of soil Analysis. Part 2: Chemical and Microbiological properties. Agronomy 9. Madison, Wisconsin.

Nigussie, H., Poesen, J., Paridaens, K., Nyssen, Jan., Deckers, S., Mitiku, H., ... Govers, G. (2007). Nutrient export and associated costs from micro-dam catchments in Tigray. In: Teklu Erkossa and Michael Menker, 2007. Soils for Sustainable Development Ethiopian Society of Soil Science. Proceeding of the Eighth Conference. April 27-28, 2006. Addis Ababa, Ethiopia.

Olsen, S. R., \& Sommers, L. E. (1982). Phosphorus. In A. L. Page, R. H. Miller, \& D. R. Keeney (Eds.), Methods of soil analysis, Part 2. Chemical Methods (pp. 403-430). ASA, Madison, WI.

Renard, K. G, \& Foster, G. R. (1983). Soil conservation: principles of erosion by water. In H. E. Degne, \& W. O. Willis (Eds.), dryland Agriculture, Agronomy Monogr. 23 (pp. 56-176), Am. Soc., Crop Sci. Soc. Am., and Soil Sci. Am Madison, Wisconsin.

Seastedt, T. R., Briggs, J. M., \& Gibson, D. J. (1991). Controls of nitrogen limitation in tallgrass prairie. Oecologia, 87, 72-79. http://dx.doi.org/10.1007/BF00323782

Stoorvogel, J. J., \& Smaling, E. M. A. (1990). Assessment of soil nutrient depletion in sub-Saharan Africa, 1983-2000. Report 28. DLO Win and Starring Center for Integrated Land, Soil and Water Research (CSC-DLO), Wageningen, Netherlands.

Wischmeier, W. H., \& Smith, D. D. (1978). Predicting rainfall erosion losses - a guide for conservation planning. U.S. Department of Agriculture, Agriculture Handbook, 537, 20-152.

Woldeyesus, S., \& Chilot, Y. (2002). Participatory client-orientation of research in low input cropping systems of Ethiopia: a viewpoint. In K. Gemechu, G. Yohannes, B. Kiflu, Y. Chilot, \& D. Asgelil (Eds.), Towards Farmers' Participatory Research: Attempts and Achievements. Proceedings of Client-oriented Research Evaluation Workshop, 16-18 October, 2001. Holetta Agricultural Research Center. Holetta, Ethiopia.

Yao, M. K., Pascal, K. T., Konaté, A. S., Tondoh, J. E., Tano, Y., \& Mikha, M. M. (2004). Tillage and manure effects on soil and aggregate -associated carbon and nitrogen. Soil Sci. Soc. Am, J., 68, 609-816.

\section{Copyrights}

Copyright for this article is retained by the author(s), with first publication rights granted to the journal.

This is an open-access article distributed under the terms and conditions of the Creative Commons Attribution license (http://creativecommons.org/licenses/by/3.0/). 